\title{
Consultation and critique: implementing cultural protocols in the reading of collaborative indigenous life writing
}

\author{
Michael Jacklin
}

Anyone working towards the publication of indigenous life narratives is aware of the significance of cultural protocols to both the narrative exchange and the writing and editing process. In the telling and the writing of an indigenous life story, protocols determining what gets told - where, when, to whom, or for whom - influence and sometimes complicate decisions regarding the final published narrative. This is the case whether the subject of the life narrative is the writer or whether the narrative is mediated by others. Indigenous protocols - including authority and moral rights over indigenous narratives and culture, kinship rights and obligations, care for country, mourning protocols, restricted knowledge, and reciprocity in the form of a return of benefits to indigenous communities - will significantly shape the production of the text. Negotiating protocols is often challenging, sometimes fraught, but always, in some form, an aspect of the writing of indigenous lives. ${ }^{1}$

This need to acknowledge and negotiate cultural protocols may also extend to the reading of indigenous life narratives, especially when those readings are published in the form of literary analysis and criticism. This is the basis of my own involvement with indigenous life stories. My academic training is in literary studies - a discipline which defines itself as working not with people in face-to-face exchanges but with texts. Engagement with producers of texts or with the families and communities of narrators and writers is not standard or even valued practice within the discipline. At least since the poststructuralist overthrow of authorial intention, seeking elucidation of a text through interlocution with its author has had little credit. ${ }^{2}$ This disciplinary insistence upon texts as objects of study, separate, distinct and removed from the persons or communities of their making, sets literary studies in sharp contrast to other fields of academic research into indigenous cultures and knowledge, where respect for cultural protocols is one of a number of ethical guidelines to which the researcher must comply. Anthropology has long been forced to grapple with the ethics of its engagement with indigenous narratives, knowledge and belief systems. Oral historians, likewise, in their interaction with and dependence upon human subjects as sources of narrative have for decades contended with the dilemmas of producing scholarly work from narratives obtained in lived relationships. My argument, then, is not with historians or anthropologists. It 
is with literary critics who turn to indigenous narratives, often produced with the involvement of historians or anthropologists, for their objects of study. Elsewhere I have suggested that respect for cultural protocols ought to apply to the reading of indigenous literature in ways similar to other avenues of indigenous research and scholarship. ${ }^{3}$ Reading indigenous lives and publishing those readings situate the literary critic in an ethical engagement with indigenous subjects not dissimilar from other academic disciplines, and fundamental to both academic and indigenous protocols is consultation. The purpose of this article, then, is not to reiterate that previous argument but to demonstrate some of the benefits and to indicate challenges that arise from consultation with the producers of indigenous life narratives. To do this I will make reference to experiences gained and dilemmas faced over the course of my $\mathrm{PhD}$ study on collaborative indigenous life writing in Australia and Canada.

There is a great deal of critical work which theorises the dynamics of collaborative life writing; most of this focuses on issues of power dissymmetries and how the voice of the narrating subject is shaped or altered - or alternatively how the integrity of that voice is maintained - in the process of reaching the printed page. ${ }^{4}$ Because literary critics restrict their engagement to available texts, much of this theoretical work on collaborative writing is, by necessity, speculative. Critics will use paratexts - the surrounding or framing texts such as introductions, prefaces, afterwords, and so on - to gain some insight into the collaborative process. ${ }^{5}$ Occasionally, an interview with the editor or writer will be available, or she or he may have published a separate academic article on the writing process. Literary theorists will then use this supplementary material to reflect upon the dynamics of collaboration and the effects of these dynamics on the published outcome. In some cases, the critic moves from commentary on perceived power differentials to a ready dismissal of the published text as failing to move beyond the colonialist framework that underlies its production. In my encounters with this type of criticism of selected indigenous life writing, I began to experience a sense of uneasiness as I wondered what the indigenous contributors to these texts, or - if they had passed on - their families or communities, would make of such critical work. This uneasiness moved me towards a commitment that if I were to publish readings of indigenous texts, I should try to contact and to consult the makers of the texts.

I was encouraged in this direction by remarks from Jeremy Beckett who, in an address given to his fellow anthropologists, spoke of the ways in which anthropology had changed over the previous decades, largely in response to theoretical shifts and critical insights in other disciplines, but also as a result of the tension between anthropology and postcolonial and cultural theory. This tension, Beckett suggests, is related to the disciplinary divide which marks literary and cultural studies as 'text based', while anthropology, through its 
practice of fieldwork, is necessarily a process of human engagement in which researchers work with individuals and communities in the production of knowledge. This difference, '[t]hat we have actually talked to the people we write about', Beckett says, 'seems particularly to get under the skin of our critics, which I of course believe conceals their insecurity about their own text-based speculations' ${ }^{6}$

My belief that consultation could aid my reading of indigenous life narratives may have been prompted by the kind of anxiety Beckett suggests, but my understanding of the role of consultation and its potential to enrich the reading of indigenous life writing grew tremendously in the very process of undertaking it. For my PhD research I had identified 12 indigenous texts - both Australian Aboriginal life narratives and Canadian First Nations texts - that I would read and critique. In Australia, I spoke with Ruby Langford Ginibi and Penny van Toorn; with Patsy Cohen and Margaret Somerville; with Roy and June Barker and Cilka Zagar; with Jackie Huggins; and with Jennifer Isaacs. ${ }^{7}$ In Canada, among the many people I met were Maria Campbell and Linda Griffiths; Daisy Sewid-Smith and Thomas Sewid; Yvonne Johnson and Rudy Wiebe; Freda Ahenakew; Heather Hodgson; Julie Cruikshank; Wendy Wickwire; and Beverly Hungry Wolf. ${ }^{8}$ Over the course of these interviews, what started out as a rather theoretical concept - that indigenous protocols for meeting and exchanging knowledge might extend to reading and commenting on indigenous texts became more thoroughly grounded and reinforced with each encounter and conversation that I became involved in. Australian author Kate Grenville has acknowledged that talking to Aboriginal people whose lives, or whose ancestors' lives, are implicated in one's writing is, at the very least, 'a matter of courtesy' ${ }^{9}$ Meeting with both indigenous and non-indigenous contributors to indigenous life writing - whether writer or editor, storyteller or family member - helped me realise that visiting and consulting was the foundation of good relations, and the beginning of ethical engagement. In reading and then writing about a published indigenous life narrative, consulting is a sign of respect - respect for the person and her or his authority over the narrative and knowledge that had been published. The question of 'Who owns the story?' is directly relevant here. Once published, a narrative moves beyond the control of its author or authors, and is open to commentaries, reviews, criticism, interpretations and re-contextualisations that its authors could not have imagined. All published work shares this fate and clearly it is neither possible nor necessary for literary critics to contact the author of each book they review or analyse. It is essential, however, that when a non-indigenous critic enters indigenous territory, represented here in indigenous life narratives, they should be aware of the protocols that guide other forms of research into indigenous lives and cultures, and be willing to respect these protocols in their own engagement with indigenous narratives and knowledge. 
Respect for cultural protocols and a willingness on the critic's part to engage in dialogue with the makers of indigenous life-writing texts can contribute significantly to the understanding of a text, often in unexpected ways. Two examples will illustrate this potential. The first of these is in relation to the Indigenous life story The two worlds of Jimmie Barker. ${ }^{10}$ In the early stages of my $\mathrm{PhD}$, I wrote an article in which I pointed towards the degree of Indigenous agency in the production of the narratives upon which this book is based. ${ }^{11}$ Jimmie Barker had been responsible for the majority of the recording process, having begun tape-recording well before he met with the non-indigenous researcher, Janet Mathews. His narratives provide a powerful account of Aboriginal identity and the struggle to maintain culture and language under the pressures of colonialist policies and practices of subjugation in north-west New South Wales. Although written by Mathews after Barker's death - based upon his tapes as well as letters and conversations - the book, I believed, was significant for the way it placed into question assumptions regarding non-indigenous control of interviewing and recording. However, my subsequent meeting with Roy Barker, Jimmie Barker's son, cast another light upon this collaborative text. As Mathews saw the book through to publication after Barker's death, she claimed copyright of the text. Roy Barker feels that, because of this, his family and the Muruwari nation have lost control of Jimmie Barker's life story. Although I was aware that Mathews held copyright, I had assumed that the Barker family's interests had also been respected. I cannot account now for why I thought this; perhaps I had naively assumed that the basic principle of Indigenous authority and moral rights over Indigenous narratives and culture had been respected. However, Roy Barker was emphatic that this was not the case. $^{12}$ Consultation here led me - a non-indigenous reader - to a deeper understanding of issues that continue to impact upon the way this published Indigenous life narrative is viewed by those close to, and affected by, its production.

A second example relates to the difficulties faced by a non-indigenous researcher looking at books published from a diverse range of indigenous cultures. Reading collaboratively-produced narratives from regions including Yolngu country in Arnhem Land, Anaiwan country in northern New South Wales, from the Kwakwaka'wakw territories of north-eastern Vancouver Island, and from Tyendinaga Mohawk Territory near the shore of Lake Ontario, meant that there was no way I could fully comprehend the culturally specific codes and practices that had contributed to any one text's making. Consulting provided an opportunity to learn something of how the narratives and texts were shaped by the cultural beliefs and practices of their makers. Specifically, I learned from speaking with Yvonne Johnson, who along with Canadian novelist Rudy Wiebe co-wrote her life story titled Stolen life: Journey of a Cree woman, that their book was designed so that the cover, and the book's opening and closing prayers 
would represent a medicine bundle, a power object of tremendous significance in Cree culture. ${ }^{13}$ A medicine bundle is something in which sacred objects are wrapped to hold their power, both to protect that power from exposure to forces from without, but also to protect the unwary or unprepared from the force within. A medicine bundle can only be opened with due ceremony, respect and protocols. That Yvonne Johnson's life story is one of sexual abuse endured from the earliest years of her childhood, and one that culminates in her involvement in a murder for which she received a 'life-25' sentence, underscores the significance of wrapping her narrative as a medicine bundle, an object of power and potentially an object of harm. ${ }^{14}$

Consulting with the indigenous contributors, the narrators or co-authors, or their families, in this way allows for critical reading enhanced by some measure of cross-cultural understanding. Native American critic Greg Sarris points out that without such insight, and without engagement with those involved in the text's production, critics

would not have any opportunity to know any story about the text except that of their own invention. Little, if anything, would inhibit their culture specific projection, which, in turn, can engender further discussion about the projection and spin the discourse further and further from the Indian narrator and her narration. ${ }^{15}$

Indeed, the unease I had experienced when reading some critical analyses of indigenous texts had been prompted by exactly this: non-indigenous critics devoting the majority of their attentions to editing and framing issues, to the neglect of the indigenous narrative, their putative object of study. Stephen Muecke made this same observation more than 20 years ago. A common approach to collaborative indigenous writing, according to Muecke, 'is to direct all critical attention to the linguistic strategies of the editors, as if these were the most salient features of the works'. ${ }^{16}$ In two decades much has changed in other disciplines, yet in literary criticism the fixation upon the non-indigenous frame remains common. Consultation, on the other hand, could help literary critics enter into more meaningful engagement with the indigenous narratives they read and comment upon.

Consultation, however, brings not only deeper understanding of indigenous texts but also moves the literary critic into sometimes ambiguous issues of research and knowledge circulation. Frances Peters-Little has written about the near impossibility of fulfilling all aspects of cultural protocol requirements in indigenous research. Particularly she has commented on the difficulties involved in protocols such as community permissions and the return of benefits to community. Deciding 'who is community' and 'what benefits a community is not straightforward', she says, and guidelines provide little help. ${ }^{17}$ Notions of community are complicated by issues of migration, by who has left town and 
who has remained, sometimes by forced separation from family and country, and by competing or overlapping family claims to status or to land. ${ }^{18}$ In my own limited involvement in matters relating to indigenous communities, the same complex issues arose. Consultation, as argued above, can provide knowledge or information that the literary critic might otherwise fail to appreciate. A critic, of course, realises that an important aspect of a life narrative is selection, determining what is included and what is left out; this is how meaning is created. For the critic, awareness of who or what is absent and why they are absent is essential to any comprehensive reading. I found, however, that in consulting with those who knew much more than was included in published texts, I was sometimes given more information than I had anticipated. In some cases I felt that the information being relayed to me, if I included it in my published critical readings, had the potential for harm. I felt especially unsettled as a non-indigenous researcher being given information relating to conflict within indigenous communities - in some cases inter-family conflict, in others disputes between family members - that if circulated could have unforeseeable consequences. And to believe that publishing in academic journals entails little risk of commentary returning to community in quite unpredicted ways is both false and, in itself, harmful. Publishing in any forum has consequences. What gets written stays written, and can return to communities in unexpected ways. ${ }^{19}$

Avoidance of harm is an ethical responsibility of research which engages with human subjects. As I have argued throughout, such ethics and protocols may very well be extended to the literary critic's engagement with indigenous texts. In other research fields, another important consideration is the return of benefits. What is it, however, that a literary critic gives back to indigenous writers, narrators, or community in a published critical reading? How does consultation regarding the production and reception of indigenous life narratives work in terms of reciprocity? In this, I take my cue from First Nations writer Daisy Sewid-Smith, from the Kwakwaka'wakw people of north-eastern Vancouver Island and daughter of James Sewid. In a rejoinder to an American anthropologist who had been invited to attend her father's potlatch - a significant event in Kwakwaka'wakw culture and one that plays an important role in Pacific Coast First Nations life writing - Sewid-Smith took issue with the non-indigenous academic's subsequently published account of the event. ${ }^{20}$ She writes that in answering this academic publicly, but outside the ceremonial space of the Big House where potlatches are performed, she is breaking with her cultural tradition, but she feels if she does not answer then the academic's words would become 'the only written record of this historic event in the academic world' ${ }^{21}$ Sewid-Smith takes issue, especially, with outsiders' interpretations of her family's, her community's, her nation's representational practices. Sewid-Smith refers to these outsiders as 'academic adjuncts', who, although perhaps invited into indigenous territory, when they leave, publish accounts without maintaining 
due process of consultation and respect for indigenous authority. I take Sewid-Smith's words seriously and accept that at most, whatever reading I offer will be that of an academic adjunct, an adjunct, however, who has made an effort to maintain relationships with those whose life narratives have provided the material for critical commentary.

This certainly has not been without difficulties. There were 29 people involved in my interviews. Maintaining relationships has been a matter of letters, phone-calls, emails, and with those close by, personal visits. For each chapter of my PhD I sent the finished material to contributors and asked for their comments. For some chapters, this meant the involvement of four or five people. Most responded positively; some took issue with the commentary, or with the arrangement, and asked for changes, which I respected. In one case, disagreement resulted from the conflicting responses of the indigenous and the non-indigenous contributors to one book. Through emails, I was able to work this through so that my chapter was satisfactory, although I felt considerable anxiety about becoming a mediator between the book's makers. In another case, however, a First Nations writer broke off our email exchanges because of a misunderstanding that I could not set right. Here, my mediation was not between co-writers, or narrator and editor, but between the indigenous writer and a number of published academic responses that she had not been aware of, but which I had discussed. The writer was dissatisfied with the implications she read between the commentary of these other critics, the placement of material from her interview and my analysis. I modified the chapter, removing the offending material, although I could not help feeling this to be an unfortunate outcome, as I had been attempting to critique the work of others who had, of course, not consulted with this indigenous writer before publishing their critiques. I remembered Eric Michaels expressing dismay at the difficulties of consultation and community vetting of his work in Yuendumu, particularly when the work of other researchers, 'who never submit[ted] a thing for comment or vetting', could be published unchallenged. ${ }^{22}$

This, however, is what the literary critic can give back. In every academic discipline it is acknowledged that 'research involving Indigenous knowledges and peoples needs to be conducted in culturally appropriate ways that fit the cultural preferences, practices and aspirations of Indigenous peoples' ${ }^{23}$ There is no reason why this could not, or should not, be the standard for academic work in literary studies which draws upon and publishes readings of indigenous life narratives. As mentioned throughout, published readings of collaboration in life writing often focus on power dissymmetries. It is necessary to acknowledge, however, that power dissymmetries are central not only to cross-cultural collaborative writing but also to the academic interest in such texts. The right to publish one's reading of another's life story is a privilege 
created by and contributing to existing structures of power. Aileen Moreton-Robinson's challenge to white feminists - that they need 'to theorise the relinquishment of power' - perhaps should be extended to literary studies, and to those who critique indigenous life writing. ${ }^{24}$ Honouring protocols and consulting is a way of acknowledging that 'Who owns the story?' bears upon the reading of a narrative as well as its production.

\section{References}

Ahenakew, Freda and HC Wolfart (eds and trans) 1992, Kohkominawak otacimowiniwawa: Our grandmothers' lives, as told in their own words, Fifth House Publishers, Saskatoon.

Beckett, Jeremy 2002, 'Some aspects of continuity and change among anthropologists in Australia or:

"He-who-eats-from-one-dish-with-us-with-one-spoon"', The Australian Journal of Anthropology 13(2) August: 127-139.

Blackman, Margaret B 1992, 'Returning home: life histories and the Native Community', Journal of Narrative and Life History 2(1): 49-59.

Brettell, Caroline B (ed) 1993, When they read what we write: The politics of ethnography, Bergin \& Garvey, Westport.

Cohen, Patsy and Margaret Somerville 1990, Ingelba and the five black matriarchs, Allen \& Unwin, Sydney.

Couser, G Thomas 2004, Vulnerable subjects: Ethics and life writing, Cornell University Press, Ithaca.

Cruikshank, Julie 1990, Life lived like a story: Life stories of three Yukon Native Elders, in collaboration with Angela Sidney, Kitty Smith, and Annie Ned, University of Nebraska Press, Lincoln.

Genette, Gerard 1997, Paratexts: Thresholds of interpretation, Trans. Jane E Lewin, Cambridge University Press, Cambridge.

Ginibi, Ruby Langford 1999, Haunted by the past, Allen \& Unwin, St Leonards. Grenville, Kate 2006, Searching for the secret river, Text Publishing, Melbourne.

Griffiths, Linda and Maria Campbell 1989, The Book of Jessica: A theatrical transformation, Coach House, Toronto.

Heiss, Anita 2002, 'Writing about Indigenous Australia - some issues to consider and protocols to follow: a discussion paper', Southerly 62(2) Summer: 197-206.

Hodgson, Heather (ed) 1989, Seventh generation: Contemporary native writing, Theytus Books, Penticton. 
Huggins, Jackie 1994, 'Respect V Political Correctness', Australian Author 26(3) Spring: 12-14.

Huggins, Rita and Jackie Huggins 1994, Auntie Rita, Aboriginal Studies Press, Canberra.

Hungry Wolf, Beverly 1982, The ways of my grandmothers, Quill, New York.

Jacklin, Michael 2002, 'Collaboration and resistance in indigenous life writing', Australian Canadian Studies 20(1): 27-45.

2004, 'Critical injuries: collaborative indigenous life writing and the ethics of criticism', Life Writing 1(2): 55-83.

-2005, 'Cross talk: collaborative indigenous life writing in Australia and Canada', PhD Thesis, Deakin University, Geelong.

2007, 'What I have done, what was done to me: confession and testimony in Stolen life: Journey of a Cree woman', Kunapipi 29(1): 19-33.

Janke, Terri 1998, 'Our culture: our future: report on Australian Indigenous cultural and intellectual property rights', Michael Frankel \& Company, Surry Hills. Available online at:

<http://www.frankellawyers.com.au/media/report/culture.pdf>

Marika, Wandjuk 1995, Wandjuk Marika: Life story, as told to Jennifer Isaacs, University of Queensland Press, St Lucia.

Mathews, Janet (ed) 1988, The two worlds of Jimmie Barker: The life of an Australian Aboriginal 1900-1972, rev. edn, Aboriginal Studies Press, Canberra. First published in 1977.

Michaels, Eric 1990, Unbecoming, EM Press, Sydney.

Moreton-Robinson, Aileen 2000, Talkin' Up to the white woman: Indigenous women and feminism, University of Queensland Press, St Lucia.

Muecke, Stephen 1984, 'The Scribes', Meridian 3(1): 41-48.

Neate, Erica and Marie Wilkinson 1997, 'Listen with your heart', Oral History Association of Australia Journal 19: 10-15.

Newton-De Molina, David (ed) 1976, On literary intention, Edinburgh University Press, Edinburgh.

Peters Little, Frances 2000, The community game: Aboriginal self-definition at the local level, Aboriginal Studies Press, Canberra. Available online at: $<$ http://www.anu.edu.au/caepr/iwepapers/Peters-Little.pdf>

_ 2003, 'The impossibility of pleasing everybody: a legitimate role for white filmmakers making black films', Australian Humanities Review (January). Available online at: <http://www.australianhumanitiesreview.org/ archive/Issue-Jan2003/peterslittle.html> 
Rigney, Lester-Irabinna 2006, 'Indigenist research and Aboriginal Australia,' in Indigenous peoples' wisdom and power: Affirming our knowledge through narratives. Julian E Kunnie and Nomalungelo I Goduka (eds), Ashgate, Aldershot: 32-48.

Robinson, Harry 1989, Write it on your heart: The epic world of an Okanagan storyteller, Wendy Wickwire (ed), Talonbooks/Theytus, Vancouver.

Sarris, Greg 1993, Keeping Slug Woman alive: A holistic approach to American Indian texts, University of California Press, Berkeley.

Sewid-Smith, Daisy 1997, 'The continuing reshaping of our ritual world by academic adjuncts', Anthropology and Education Quarterly, 28(4) December: 594-602.

Spradley, James (ed) 1972, Guests never leave hungry: The autobiography of James Sewid, a Kwakiutl Indian, McGill-Queens University Press, Montreal and Kingston.

Theisz, RD 1981, 'The critical collaboration: introductions as a gateway to the study of Native American bi-autobiography', American Indian Culture and Research Journal 5(1): 65-80.

Torres, Patricia Mamajun 1994, 'Interested in writing about Indigenous Australians?' Australian Author 26(3) Spring: 24-25.

Wheatley, Nadia 1994, 'Black and white writing: the issues,' Australian Author 26(3) Spring: 20-23.

Wiebe, Rudy and Yvonne Johnson 1998, Stolen life: The journey of a Cree woman, Alfred A. Knopf, Toronto.

Wimsatt, WK and MC Beardsley 1976, 'The intentional fallacy', in On literary intention, David Newton-De Molina (ed), Edinburgh University Press, Edinburgh: 1-13.

Wolcott, Harry F 1996, 'Peripheral participation and the Kwakiutl potlatch', Anthropology and Education Quarterly 27(4): 467-492.

Zagar, Cilka (ed) 2000, Goodbye riverbank: The Barwon-Namoi people tell their story, Magabala, Broome.

\section{ENDNOTES}

${ }^{1}$ There are numerous publications outlining cultural protocols and their application to research in areas of indigenous knowledge. For the most comprehensive coverage, see Janke 1998; also, Huggins 1994; Neate and Wilkinson 1997; Torres 1994; Wheatley 1994; Heiss 2002.

2 Rejection of authorial intention in literary analysis pre-dates poststructuralism, of course, with Wimsatt and Beardsley's article 'The intentional fallacy' signalling the textual turn in New Criticism in the 1940s: Wimsatt and Beardsley 1976. For an excellent collection of articles on the conundrum of intention, see Newton-De Molina 1976.

3 This was the primary outcome of my PhD thesis, 'Cross talk: collaborative indigenous life writing in Australia and Canada', submitted to Deakin University in 2004. Based on a process of both reading and 
consultation with the makers of indigenous life writing texts, I argued that literary criticism needs to take into account the co-operative aspects of textual production as well as the constraining factors that shape the outcome of collaborative texts. The thesis also insists upon the importance of non-indigenous critics acknowledging the centrality of indigenous protocols in both the production and reception of collaborative indigenous life writing. For a condensed version of this see Jacklin 2004.

4 See especially the work of Couser 2004.

${ }^{5}$ Paratexts is a term borrowed from Genette 1997. For an early and important work on the use of introductions and other 'threshold' material in the analysis of collaboratively produced texts, see Theisz 1981.

6 Beckett 2002: 129-130.

7 See Ginibi 1999; Cohen and Somerville 1990; Zagar 2000; Huggins and Huggins 1994; Marika 1995.

8 See Griffiths and Campbell 1989; Spradley 1972; Wiebe and Johnson 1998; Ahenakew and Wolfart 1992; Hodgson 1989; Cruikshank 1990; Robinson 1989; Hungry Wolf 1982. With each text read, I attempted to contact both the Indigenous and non-Indigenous contributors. This was not always possible, due to distance, or non-replies, or in some cases to the passing on of one or the other participant. From the list of contributors given above, 12 are Indigenous and eight non-Indigenous. For example, Ruby Langford Ginibi is a pre-eminent Aboriginal author from Bun djalung country in New South Wales, while Penny van Toorn is a non-Indigenous academic who edited Ginibi's book Haunted by the past, a biography of her son Nobby Langford: Ginibi 1999.

${ }^{9}$ Grenville 2006: 130.

10 Mathews 1977.

11 Jacklin 2002.

12 Interview with Roy and June Barker, recorded 23 April 2002, Lightning Ridge, New South Wales.

13 Wiebe and Johnson 1998.

14 For a detailed reading of Wiebe and Johnson's book as a spirit bundle, see Jacklin 2007.

15 Sarris 1993: 45.

16 Muecke 1984: 45.

17 Peters Little 2003: para 12.

18 Peters Little 2000: 15-20.

${ }^{19}$ Amongst the works relating to the return of academic writing to a community of origin, see especially Brettell 1993; also Blackman 1992.

20 The American anthropologist is Harry Wolcott. See Wolcott 1996.

${ }^{21}$ Sewid-Smith 1997: 598.

22 Michaels 1990: 102.

23 Rigney 2006: 46.

24 Moreton-Robinson 2000: 186. 